\title{
Enzymatic Introduction of Cyanide into Imine for Constructing Optically Active Compound by $(R)$-Oxy-nitrilase in Almond Meal
}

\author{
Teckheon Lee and Yonghyun Ahn \\ Department of ('hemisty. Dankook lniversity, Seoul 140-7/4, Korea \\ Received JHI 22, 2002
}

Key Words : Cyanide, Imine, Oxynitrilase, Hydrexynitrile lyase

Enantiomerically pure compounds are increasingly used by the phannaceutical industry. lntroducing cyanide into imine has been used as a method of synthesizing unnatural amino acids. There are many examples of the cyamation of imine by chemical methods. ${ }^{i}$ Strecker reaction is one of the best methods to make an optically active nitrogen-containing molecules. Trimethylsilyl cyanide $\left(\mathrm{Me}_{3} \mathrm{SiCN}\right)$ was the best cyanation agent in the presence of Ti-tripeptide Schiff base complex. ${ }^{2}$ Lewis acid. ${ }^{3}$ or cyclic dipeptide. ${ }^{4}$

These optically pure compounds can be efficiently prepared by enzy matic catalysis. Oxynitrilases are enzymes. which catalyze the formation and cleavage of cyanohydrins. "The cyanolydrin formation reaction proceeds by stereoselective addition of lydrogen cyanide to aldehydes or ketones to give enantiopure $\alpha$-hydrosy nitriles. These chiral cyanohydrins are precursors for numerous compounds such as pyrethroids, $\alpha$-hydroxyacids and 2-amino alcohols." This simple method of $\mathrm{C}-\mathrm{C}$ bond formation has become a promising method of obtaining a number of biologically active compounds.

In this article, we describe our study on the synthesis of optically active $\alpha$-amino nitrile, using acetone cyanohydrine as a transcyanation agent and the powdered. defatted almond meal as a catalyst. ${ }^{?}(R)$-(+)-oxynitrilase in almond meal were used to introduce a nitrile group into imine instead of a carbonyl group. The acetone cyanohydrine is an optimum reagent in the enzyme reaction because it provides a low $\mathrm{HCN}$ concentration. It prevents the chemical addition of $\mathrm{HCN}$ to imine under high $\mathrm{HCN}$ concentration. The powdered almond meal is a cheap catalyst. which can be used without further purification.

The enzy matic reactions were carried out in a misture of isopropyl alcohol $(30 \mathrm{~mL})$ and $0.2 \mathrm{~N}$ phosphate buffer $(\mathrm{pH}=7.8 .5 \mathrm{~mL})$. The defatted almond meal $(500 \mathrm{mg})$ and imine $[(R)-1 \mathrm{a}]$ in isopropyl alcohol (1 $\mathrm{mL})$ were added consecutively: The mixture was stirred at room temperature for 40 hrs. This method allowed us to obtain the $(R)$ enriched diastereomer of $\mathbf{2 a}$ in a $81 \%$ yield.

Using defatted almond meal to catalyze the addition of $\mathrm{CN}$ group to the imines has made it possible for preparing optically active $(R)$ - $\alpha$-amino nitriles. which predominated over the (\$)-isomer. All $\alpha$-amino nitriles (2a-2m) were obtained with moderate diastereopurity of up to $81 \%$ for $(R, R)$-isomers when the configuration of the nitrogen auxiliary was $R$.

lt is interesting to compare this with the results of diastereoselective addition of $\mathrm{HCN}$ to aldimine derived from (S)-(-)- $\alpha$-methylbenzy lamine. We anticipated that the opposite ratio of two diastereomers could be obtained. However. the $(R)$ - $\alpha$-amino nitrile was obtained as a major isomer as well as the same value of diastereoisomer ratio. Almost the same values of diastereoisomer ratio was obtained in various substrates. The diastereoisomeric ratios of the products were determined by means of ${ }^{1} \mathrm{H}$ NMR using the signals of benzyl protons as key signals. The signals of benzyl protons $\mathrm{C} \underline{\mathrm{H}}(\mathrm{Me}) \mathrm{Ph}$ appeared in well separated quartets: the downfield (major) at $\delta+.23$ ppm and the upfield (miner) at $\delta 3.98$ ppin.

When the configuration of the nitrogen auxiliary was $R$. the $(R, R)$ - $\alpha$-amino nitriles were the resulting major products. However, when $(S)$-imines were applied in enzy me reaction. (S, $R$ )- $\alpha$-amino nitriles were obtained as major compounds in stead of $(S, S)$ - $\alpha$-amino nitriles. It is worth noting that the effect of the nitrogen auxiliary in imines was not observed. This result shows that the enzy me plays a major role in the

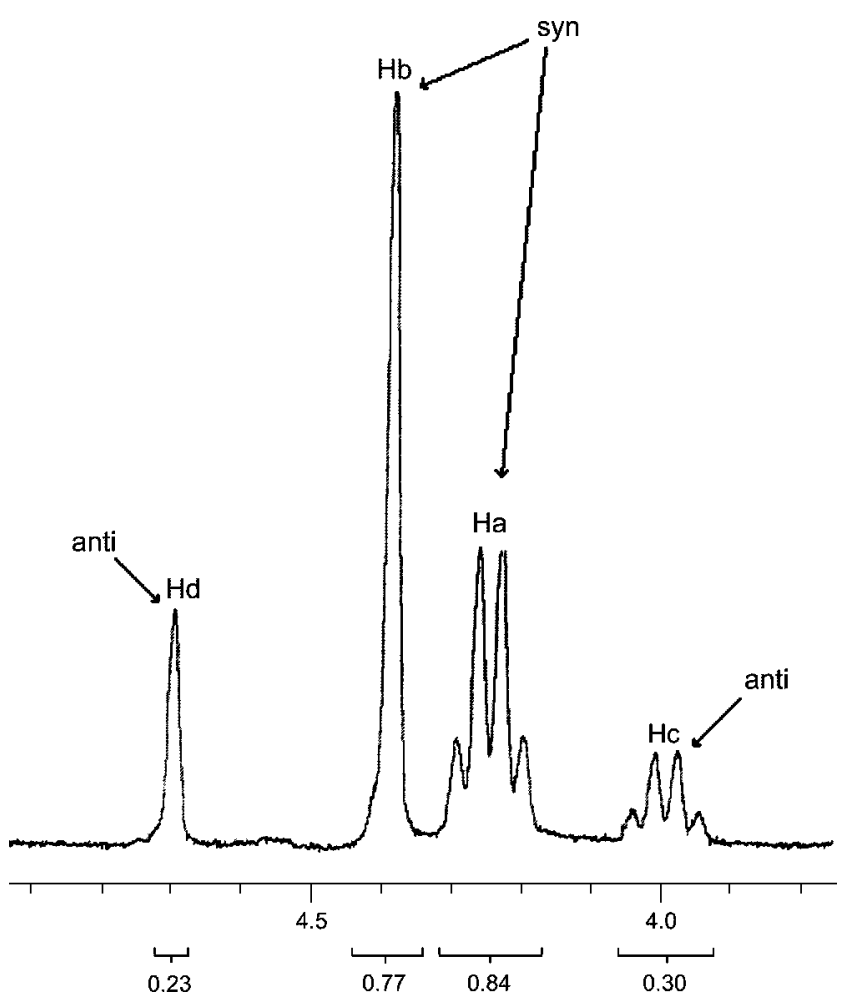

Figure 1. 'H NMR spectrum of 2 a. 
Table 1. Fnzsmatic introduction of cyanide to imine

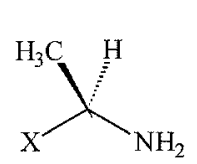

$(R)$
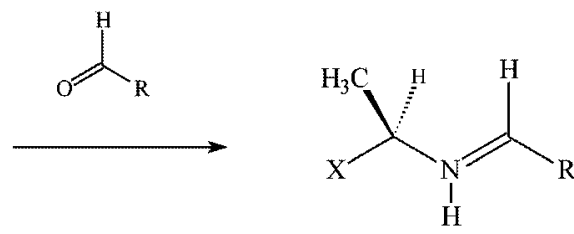

$(R)$ - 1a 1 le

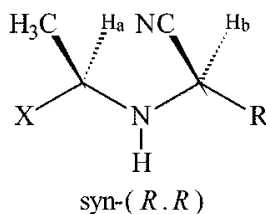<smiles>[X]C(C)(C)NC([R])([1H])[13CH3]</smiles>

anti- $(R . S)$

\begin{tabular}{|c|c|c|c|c|c|c|c|}
\hline \multirow{2}{*}{ Run } & \multirow{2}{*}{$\operatorname{lmine}$} & \multirow{2}{*}{$\mathrm{X}$} & \multirow{2}{*}{ R } & \multirow{2}{*}{ Product } & \multirow{2}{*}{ Yield $\left({ }^{0} 0\right)$} & \multicolumn{2}{|c|}{ d.r. } \\
\hline & & & & & & $(R . R):(R . S)$ & $(S R):(S . S)$ \\
\hline 1 & $(R)-\mathbf{1 a}$ & phespy. & $\mathrm{C}_{4} \mathrm{H}_{5-}$ & $2 a$ & 81 & $77: 2.3$ & - \\
\hline 2 & $(R)-\mathbf{1 b}$ & phespy. & $3,5-\left(\mathrm{Cl} \mathrm{I}_{3} \mathrm{O}\right)_{2} \mathrm{C}_{+} \mathrm{H} \mathrm{I}_{3-}$ & $2 b$ & 76 & $74: 26$ & - \\
\hline 3 & $(R)-\mathbf{1 c}$ & phejuyl- & $\mathrm{CIH}_{3} \mathrm{C} \mathrm{II}_{2} \mathrm{ClII}_{3-}$ & $2 \mathrm{c}$ & 50 & $79: 21$ & - \\
\hline 4 & $(R)-\mathbf{1 d}$ & 1-naphthys. & $\mathrm{CI}_{3} \mathrm{CII} \mathrm{CIII}_{2}-$ & $2 \mathrm{l}$ & 42 & $75: 25$ & - \\
\hline 5 & $(R)-\mathbf{e}$ & 1-naphthys]- & $4-\left(\mathrm{CII}_{3} \mathrm{O}\right) \mathrm{C}_{\mathrm{H}} \mathrm{II}_{4^{-}}$ & $2 \mathrm{e}$ & 42 & $75: 25$ & - \\
\hline 6 & $(S)-1 f$ & phesy. & $\mathrm{C}_{k} \mathrm{I} \mathrm{I}_{\overline{3}-}$ & $2 \mathrm{f}$ & 49 & - & $77: 23$ \\
\hline 7 & $(S)-1 \underline{g}$ & phesugl- & $3,5-\left(\mathrm{ClI}_{3} \mathrm{O}\right)_{2} \mathrm{C}_{\mathrm{k}} \mathrm{II}_{3-}$ & $2 \mathrm{~g}$ & 92 & - & $72: 28$ \\
\hline 8 & $(S)-1 h$ & phesugl- & $\mathrm{CII}_{3} \mathrm{CII} \mathrm{I}_{2} \mathrm{CII}_{3-}$ & $2 \mathrm{~h}$ & 57 & - & $81: 19$ \\
\hline 9 & $(S)-\mathbf{I i}$ & 1-naph1luy. & $\mathrm{CII}_{3} \mathrm{CII} I_{2} \mathrm{CII}_{2-}$ & $2 \mathrm{i}$ & 43 & - & $72: 28$ \\
\hline 10 & $(S)-\mathbf{l j}$ & I-naphthỵ]- & $4-\left(\mathrm{CII}_{3} \mathrm{O}\right) \mathrm{C}_{4} \mathrm{II}_{4}-$ & $2 j$ & 48 & - & $76: 24$ \\
\hline 11 & $(S)-1 \mathbf{k}$ & phesuyl- & $4-\left(\mathrm{CII}_{3} \mathrm{O}\right) \mathrm{C}_{\mathrm{H}} \mathrm{II}_{4^{-}}$ & $2 k$ & 44 & - & $79): 21$ \\
\hline 12 & $(S)-11$ & 1-naph1]y:]- & $\mathrm{C}_{k} \mathrm{I} \mathrm{I}_{5-}$ & 21 & 48 & - & $73: 27$ \\
\hline 13 & $(S)-1 m$ & I-naphthỵ]- & $3,5-\left(\mathrm{Cl} \mathrm{I}_{3} \mathrm{O}\right)_{2} \mathrm{C}_{\mathrm{K}_{1}} \mathrm{I}_{\mathrm{3}^{-}}$ & $2 m$ & 40 & - & $71: 29$ \\
\hline
\end{tabular}

1) The ratio of d.r. was based on the ${ }^{3} \mathrm{H}$-nme spectrum. 2) The vield was based on the misture ol diasteromers.

introduction of cyanide into imine. In the spectra of $(R, R)$ 2a. the signal due to the methine proton $\left(\mathrm{H}_{1}\right)$ at the $\alpha$ position to the cyano group was observed at 4.38 ppm. while that of the methine proton $\left(\mathrm{H}_{3}\right)$ of $(R, S)$-2a was observed at 4.69 ppm. One of the reasons is that $\mathrm{H}_{\mathrm{l}}$ is located above the benzene ring and is magnetically shielded."

Nonenzymatic reaction of the aldehyde with cyanide is competed with enz matic reaction. To solve the competitive reaction. the cyanolydrine which produces a low concentration of hydrogen cyanide is used in the enzy matic reaction. To examine the nonenzymatic reaction of the imine with cyanide. the imine was stirred with acetone cyanohydrine overnight without enzyme. Clearly; there was no progress of any reaction.

In summary low priced of almond meal containing oxy nitilase was used to introduce cranide into imines instead of carbon-oxygen double bond, and $\alpha$-amino nitriles were obtained with a moderate diasteromeric ratio. We have extended the use of $(R)$-oxynitrilase in almond meal to the synthesis of $\alpha$-amino acids.

\section{Experimental Section}

General procedures. The chemicals for the synthesis of imines were commercially asailable. 'H NMR spectra were recorded on Varian $(200 \mathrm{MHz})$ spectrometer using $\mathrm{CDCl}_{z}$ as a solvent and internal standard. Coupling constants $(f)$ are given in $\mathrm{Hz}$. The defatted almond meal was purchased from Sigma Co. Inc. (U.S.A.) The optically active (S)- and $(R)$ $(+)$ - $\alpha$-methylbenzy lamine were commercially available.

Synthesis of imines $(R)-1$ a. The $(R)-(+)-\alpha$-methylbenzylamine (302 $\mathrm{mg}, 2.5 \mathrm{mmol}$ ) was added into the benzaldehyde (212 $\mathrm{mg} .2 \mathrm{mmol})$ in dichloromethane $(15 \mathrm{~mL})$ at room temperature in the presence of + A molecular sieves $(0.2 \mathrm{~g})$ and then refluxed for 17 hrs. The reaction progress was monitored by TLC. After the reaction was completed. the molecular sieves were filtered and the reaction solvent was exaporated. The crude imine was used for enzyme reaction without further purification.

Enzymatic cyanation of imine. In a typical procedure. to the solution of almond meal $(500 \mathrm{mg})$ in mixture of isoprophyl alcohol $(30 \mathrm{~mL})$ and $0.2 \mathrm{~N}$ phosphate buffer $(\mathrm{pH}=$ 7.8. $5 \mathrm{~mL}$ ) was added the solution of imine $[(R)-1 \mathrm{a}](418$ mg. $2 \mathrm{mmol}$ ) in isoprophyl alcohol ( $1 \mathrm{~mL}$ ) and acetone cranohydrin $(340 \mathrm{mg} .4 \mathrm{mmol})$ consecutively. The reaction progress was monitored by TLC. When the reaction was completed. the enzime was filtered through celite, and the solvent was evaporated under reduced pressure. The product 2a was isolated by column chromatography on silica gel (solvent hexane : ethyl acetate $=9: 1$ ). A 77:23 mixture of $(R, R)-\mathbf{2} \mathbf{a}$ and $(R, S)$-2a was obtained in $81 \%$ yield. The diastereomers were separated by repeated column chromato- 
graplỵ.

${ }^{\mathrm{l}} \mathrm{H}$ NMR (CDCl. $\left.200 \mathrm{MHz}\right)$ sỵn-( $\left.R, K\right)$-isomer (2a) $\delta 1.43$ (d. $3 \mathrm{H}, J=6.4 \mathrm{~Hz}$ ) 1.72 (bs. $1 \mathrm{H}$. NH) 4.24 (q. $1 \mathrm{H}, J=6.4$ Hz). 4.39 (s. lH). 7.15-7.85 (m, loH); anti-( $R, S)$-isomer (2a) $1.4 \mathrm{l}$ (d. $3 \mathrm{H}, J=6.4 \mathrm{~Hz}), 1.79$ (bs. $\mathrm{lH} . \mathrm{NH}), 3.99$ (q. $1 \mathrm{H}, J=$ $6.4 \mathrm{~Hz}) .4 .70(\mathrm{~s}, \mathrm{lH}) .7 .15-7.85(\mathrm{~m} .10 \mathrm{H})$.

Achnowledgment. The present research was conducted by the research fund of Dankook University in 2000 .

\section{References}

1. (a) Kobayashi. S.: Ishitani. H. (hem. Rev. 1999. 90. 1069. (b) Fache. F.: Schulz. E.: Lommasino. M. L.: Lemaire. M. (hem. Rev? 2000. 100.2159.

2. Krucger, C. A.: Kuntz., K. W.: Dzicrba, C. D.: Wirsehun. W. G.: Gleason, J. D.: Snapper, M. I... I Ioverda. A. I1. J. Am. C $/ k m$. Soc. $1999,121,4284$.

3. lovel. 1.: Golomba. L.: Popelis. J.: Lukerics. E. Ippl. Organomefal. (hem. 2002. 16. 133.

4. Iyer. M. S.: Gigstad. K. M.: Namdev. N. D.: Lipion. M. $J$ : im. (hem. Soc 1996. 118.4910.

5. (a) Griengl. I.: Schwab, H.: Fechter. M. Thonts in Biotechologe 2000, 18, 252. (b) Schmidt. M.: Gricngl. HI. Topics in Curpent Chemistry 1999.201. 193. (c) Cregory, R. J. Chem. Rka 1949. 99. 3649. (d) Griengl. H.: Hickel. A.: Johnsen. D. V.: Krant. C.: Schmidt. M.: Schwab. H. Chem. C'onm 1997. 1933.

6. (a) Matsuo. T.: Nishiinka. T.: Hirano. M.: Suzuki. Y.: T'sushima. $\mathrm{K}$ : Itava, N.: Yoshioka. II. Resfic Sici. 1980. H1. 202. (b) Brussec. J.: Loos. W. T.: Kruse, C. G.: Vatn der Gen. A. Tetrohedrom 1990. 46. 979. (c) Fettenberger. F.: Gutterer. B.: 7iegler. T. Likbigy .tnn. (Wem. 1991. 269. (d) Elliot. M.: Janes. N. F'.: Khambay. B. P. S.: P'ulman. D, A. Pestic. Sici 1983. 1f. 182. (e) Jones. J. B. Tetrahedron 1986. 1f. 3351, (1) Jang. J.: Lee. Y.: Alm. Y. Bull. Nonan Chem. Soc, 1997, 18.254

7. (a) Ognyanos, V.: Datchera, V.: Kiler, K. J. Am. Chem. Soc: 1991. H.3. 6992. (b) Iluuhtanen. T.: Kanerva, I. Fetromedron: Asymmetry 1992. 3. 1223. (c) Lin. G.: Han S.: Li. L. Tetrahedron 1999. 55.3531

8. Inaba. T.: Fujita. M.: Ogura. K. J. Org. Chem. 1991. 56. 1274. 